\title{
TATA RUANG LINGKUNGAN KAMPUNG BATIK DI JAKARTA SEBAGAI KAWASAN WISATA INDUSTRI RUMAH TANGGA
}

\author{
Widya Katarina; Nina Nurdiani; Yosica Mariana \\ Architecture Department, Faculty of Engineering, BINUS University \\ Jln. K.H. Syahdan No. 9, Palmerah, Jakarta Barat 11480 \\ E-mail: w.katarina@yahoo.com
}

\begin{abstract}
Research on Kampung Batik Spatial Environment in Jakarta as Household Industrial Area Tourism conducted in Kampung Batik Palbatu through descriptive approach. This study aims to identify the characteristics of the environment and the potential area of Kampung Batik in Jakarta. Data collection in the field carried out by the method of observation and the mapping of spatial design of buildings and the environtment. Data analysis was performed by descriptive analysis. The study results showed that the Kampung Batik Palbatu as batik village in Jakarta, which was conceived and developed by a community group of batik lovers, demonstrated slow development. Image or the character of the environment of the region of Kampung Palbatu as Kampung Batik is yet to be seen, since the elements of the image-forming region are not clear. The potential of the region as the region of home industry namely Kampung Batik has started there, but lacks of supports from the government, and the local community.
\end{abstract}

Keywords: Batik hometown, Jakarta, the potential of the region the spatial environment

\begin{abstract}
ABSTRAK
Penelitian mengenai Tata Ruang Lingkungan Kampung Batik di Jakarta sebagai Kawasan Wisata Industri Rumah Tangga dilakukan di Kampung Batik Palbatu melalui pendekatan deskriptif. Penelitian ini bertujuan untuk mengidentifikasi karakteristik lingkungan dan potensi kawasan Kampung Batik di Jakarta. Pengumpulan data di lapangan dilakukan dengan metode pengamatan (observasi) dan pemetaan terhadap rancangan tata ruang bangunan dan lingkungannya. Analisis data dilakukan dengan analisis deskriptif. Hasil studi memperlihatkan bahwa Kampung Batik Palbatu sebagai kampung batik di Jakarta yang digagas dan dikembangkan oleh kelompok masyarakat pencinta batik menunjukkan perkembangan yang lambat. Citra atau karakter lingkungan kawasan Kampung Palbatu sebagai Kampung Batik belum terlihat, karena elemen pembentuk citra kawasan tidak jelas. Potensi kawasan sebagai kampung industri rumah tangga yaitu kampung batik sudah mulai ada, namun kurang mendapat dukungan dari pemerintah dan dari masyarakat setempat.
\end{abstract}

Kata kunci: kampung Batik, Jakarta, potensi kawasan, tata ruang lingkungan 


\section{PENDAHULUAN}

Saat ini upaya untuk melestarikan kearifan lokal dan budaya sedang giat dilaksanakan. Upaya ini dilakukan dengan memperkuat apresiasi masyarakat terhadap nilai-nilai lokal yang melemah dan pudar seiring dengan perkembangan jaman dan teknologi. Perkembangan teknologi dan ilmu pengetahuan, serta pertumbuhan ekonomi yang meningkat adalah bagian dari proses modernisasi. Seyogyanya modernisasi tidak menggugurkan nilai-nilai tradisi yang sudah lama membentuk kebudayaan yang utuh. Seringkali modernisasi meruntuhkan nilai tradisi. Pembaharuan prinsip-prinsip arsitektur tradisional yang otentik, dengan cara nilai-nilai hakiki perlu dipertahankan, tata nilai baru dicerna dan diakrabkan dengan apa yang membudaya di masyarakat, sehingga nilai-nilai lokal akan tetap lestari sepanjang jaman. Pada wilayah budaya dimana adat dan kepercayaan lama tetap hidup di tengah masyarakat pendukungnya, maka dapat dipastikan kearifan lokal tidak akan punah (Soeroto, 2003).

Kampung Batik Palbatu yang terletak di pusat kota Jakarta merupakan kampung yang dibangun atas kesadaran masyarakat dan generasi mudanya dengan swadaya warga pada tahun 2011. Kampung ini menjadi khas dengan munculnya batik sebagai karakter lingkungan saat ini. Upaya ini selain bertujuan untuk melestarikan nilai-nilai kearifan lokal dan sejarah ilmu batik juga memberi edukasi tentang pengertian proses atau tahapan cara membatik yang kini sudah banyak dilupakan masyarakat. Aneka warna dan motif batik menghiasi dinding rumah hingga jalan di kompleks perumahan Palbatu - Jakarta (Gambar 1). Corat-coret artistik itu dihasilkan warga Palbatu dalam upaya melestarikan keberadaan batik di Jakarta melalui upaya mewujudkan Kampung Batik sebagai kawasan wisata industri rumah tangga. Harapan warga kampung Batik Palbatu selain menjadikan kawasan industri rumah tangga, juga agar masyarakat dan generasi mudah dapat membuat batik Betawi atau batik Jakarta (Juvita, 2012).

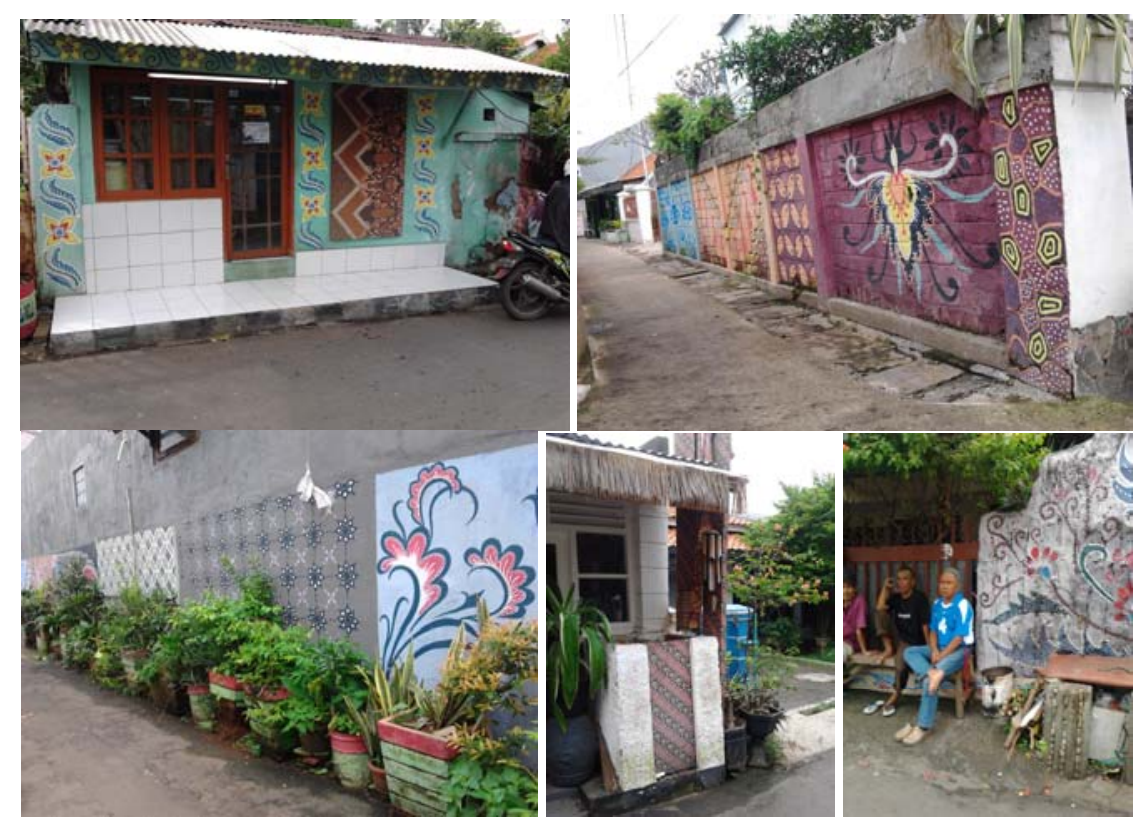

Gambar 1 Suasana lingkungan kampung Batik Palbatu, kelurahan Menteng Dalam, kecamatan Tebet, Jakarta Selatan.

Sumber: Dokumentasi tim peneliti Binus, 2013 
Untuk dapat mewujudkan kampung Batik menjadi kampung wisata industri rumah tangga, khususnya batik Betawi atau batik Jakarta, maka perlu kajian lingkungan kampung Batik terkait konsep-konsep revitalisation kawasan, renewal kawasan ataupun redevelopment kawasan. Menurut UU No.2 /1992, Revitalisasi adalah upaya untuk memvitalkan kembali suatu kawasan atau bagian kota yang dulunya pernah vital/hidup, akan tetapi kemudian mengalami kemunduran atau degradasi. Urban renewal adalah upaya perawatan kembali suatu wilayah dengan mengganti sebagian atau keseluruhan unsur-unsur lama dengan unsur-unsur baru dengan tujuan untuk meningkatkan vitalitas dan kualitas lingkungan sehingga kawasan tersebut memberi kontribusi yang lebih baik bagi kota keseluruhan. Redevelopment adalah pembangunan kembali kawasan kumuh atau kawasan bongkaran (Ramdlani, 2012)

Penelitian yang terkait arsitektur bangunan dan lingkungan Kampung Batik di Jakarta belum banyak dilakukan baik yang terkait gambaran umum masyarakatnya, latar belakang kebudayaannya dan potensi kawasan yang terdapat di kampung tersebut. Untuk mewujudkan harapan masyarakat menjadikan kampung Batik sebagai kampung wisata industri rumah tangga, khususnya industri batik Betawi atau batik Jakarta, juga dalam rangka melestarikan warisan budaya, maka penelitian mengenai Tata Ruang Lingkungan kampung Batik sebagai Kawasan Wisata Industri Rumah tangga. Penelitian dimulai dengan mengetahui karakteristik lingkungan dan potensi kawasan.

Pada dasarnya Kampung Batik Pal Batu dibangun tidak hanya untuk warga sekitar kampung tersebut melainkan untuk semua warga Jakarta yang ingin terlibat aktif dalam proses kreatif tersebut. Pelestarian tersebut kini dapat kita lihat dalam bentuk ekspresi motif-motif batik pada lorong-lorong jalan atau pada dinding rumah, pada jalan-jalan menuju perkampungan tersebut dan lain sebagainya. Keinginan masyarakat untuk menjadikan kawasan tersebut sebagai kampung wisata industri rumah tangga memerlukan studi lebih dahulu mengenai: (1) Bagaimana karakter dan pola tata ruang lingkungan dan bangunan yang ada di Kampung Batik tersebut saat ini, (2) Potensi kawasan apa saja yang ada dan harus dimunculkan untuk mendukung terciptanya kawasan wisata industri rumah tangga. Untuk menjawab pertanyaan tersebut maka perlu diadakan penelitian mengenai Tata Ruang Lingkungan kampung Batik sebagai Kawasan Wisata Industri Rumah tangga.

Tujuan Penelitian adalah untuk mengidentifikasi arsitektur Kampung Batik di Jakarta mengenai pola tata ruang bangunan dan lingkungan serta potensi kawasan Kampung Batik di Jakarta. Warisan budaya Indonesia sangat beragam bentuknya. Arsitektur kampung wisata industri rumah tangga adalah salah satu warisan budaya yang perlu dilestarikan dan dikembangkan untuk meningkatkan kesejahteraan masyarakat. Nilai-nilai budaya akan tetap dapat diapresiasikan oleh masyarakat sehingga tetap lestari.

\section{METODE}

Penelitian mengenai Tata Ruang Lingkungan Kampung Batik di Jakarta sebagai Kawasan Wisata Industri Rumah Tangga termasuk jenis penelitian deskriptif yang bertujuan untuk mengidentifikasi, mengetahui dan memahami karakteristik lingkungan dan potensi kawasan Kampung Batik di Jakarta. Pengumpulan data di lapangan dilakukan dengan metode pengamatan (observasi) dan pemetaan terhadap rancangan tata ruang bangunan dan lingkungan di kampung tersebut. Analisis data dilakukan dengan analisis deskriptif.

Penelitian mengambil lokasi di Kampung Batik Palbatu, Kelurahan Menteng Dalam, Kecamatan Tebet, Jakarta Selatan. Setting penelitian Tata Ruang Lingkungan Kampung Batik sebagai Kawasan Wisata Industri Rumah Tangga dilakukan di bagian wilayah Kampung Batik Palbatu yang memiliki karakteristik arsitektur lingkungan yang menggunakan pola-pola batik sebagai ciri khas lingkungan dan menjadi cikal bakal keinginan masyarakat untuk mewujudkan kampung wisata di Jakarta. 


\section{HASIL DAN PEMBAHASAN}

Batik Indonesia sudah ada sejak abad XIII, merupakan warisan budaya dari nenek moyang yang memulai tradisi membatik di atas daun lontar. Warisan budaya nenek moyang ini sudah ditetapkan UNESCO sebagai warisan budaya tak benda tingkat dunia pada 2 Oktober 2009. Kini batik berkembang di Indonesia dengan berbagai corak yang beragam.

\section{Lokasi Kampung Batik Palbatu}

Secara administratif Kampung Batik Palbatu termasuk wilayah Kelurahan Menteng Dalam, Kecamatan Tebet, Kotamadya Jakarta Selatan, DKI Jakarta. Lokasi Kampung Batik Palbatu berada di RW 04 yakni RT 14 dan RT 06. Area permukiman di RT 14 merupakan area permukiman padat penduduk, sedangkan area permukiman di RT 06 merupakan area permukiman terencana dan kondisi lingkungannya cukup baik.

Lokasi kampung ini mudah dijangkau dari pusat kota Jakarta, karena wilayahnya strategis yaitu berada di antara daerah Kuningan, Gatot Subroto, Tebet dan Casablanka, yang mudah dijangkau baik dengan kendaraan pribadi maupun kendaraan umum (lihat gambar 2). Kawasan ini merupakan perpaduan antara perumahan formal dan permukiman padat penduduk yang dekat dengan daerah komersial seperti perkantoran, pusat-pusat perbelanjaan, hotel dan Central Business Distric (CBD).

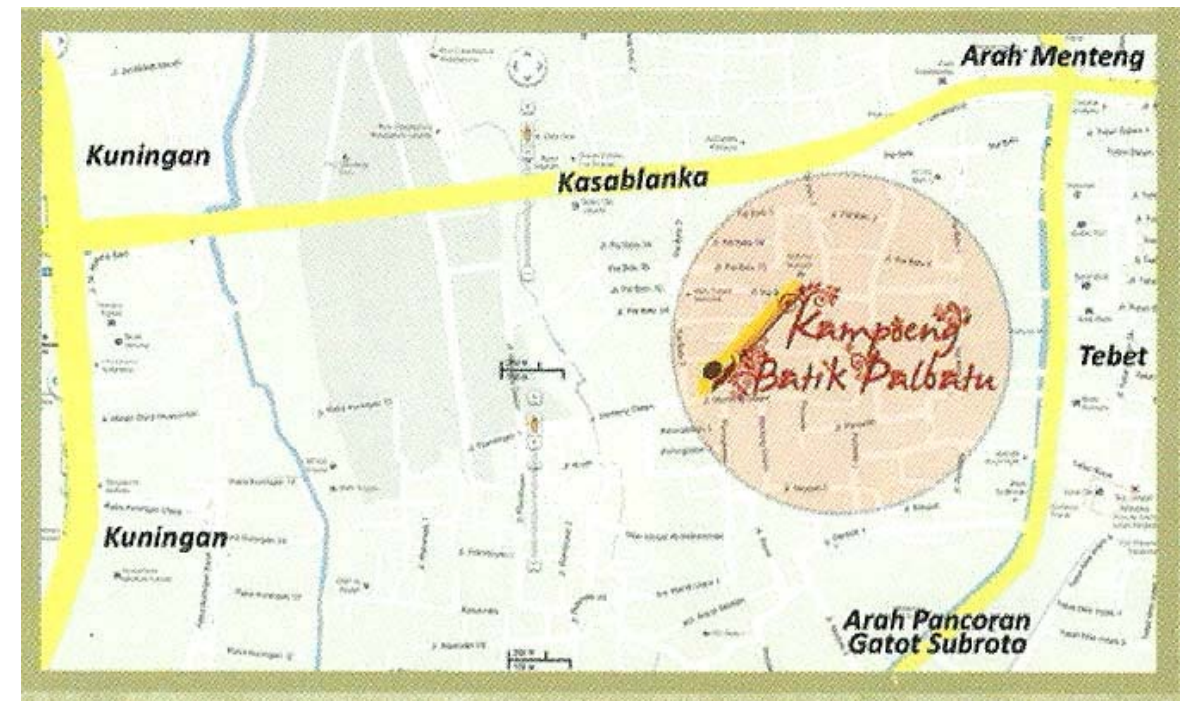

Gambar 2 Lokasi Kampung Batik Palbatu, Jakarta Selatan. Sumber: Kampung Batik Palbatu, 2013

Kampung Batik Palbatu memiliki batas-batas wilayah di sebelah utara berbatasan dengan jalan Palbatu 4, di sebelah selatan berbatasan dengan jalan Persada, di sebelah barat berbatasan dengan jalan Palbatu 2 dan jalan Palbatu 7 dan di sebelah timur berbatasan dengan jalan Palbatu 1. Lokasi daerah Palbatu dahulu dekat dengan sentra batik ibukota Jakarta di daerah Kuningan, yang menambah nilai sejarah perkembangan batik, khususnya di Betawi. Melalui keberadaan Kampung Batik Palbatu, masyarakat Jakarta dan sekitarnya dapat belajar membatik dan mengetahui sejarah batik Betawi yang kaya akan nilai-nilai budaya setempat. 


\section{Sejarah Kampung Batik Palbatu}

Berkembangnya kampung Batik Betawi dimulai di tahun 2011 yang berawal dari gagasan dua pencinta batik Betawi yang tinggal di lingkungan permukiman kampung Palbatu, yaitu Budi Iwan Darmawan dan Budi Dwi Harry Hariyanto. Gagasan ini timbul dari keprihatinan terhadap pelestarian Batik Betawi dan upaya memberikan kegiatan kreatif bagi masyarakat sekitar, khususnya kaum pemuda-pemudi atau ibu-ibu setempat agar memiliki kegiatan yang bernilai positif dan memberi nilai ekonomi bagi warganya. Harapan diwujudkannya kampung Batik Betawi agar tradisi membatik dapat bangkit kembali dan karya-karya batik yang kreatif dapat lahir dari masyarakat Palbatu.

\section{Program Kampung Batik Palbatu}

\section{Produksi Batik - Workshop Batik Pewarna Alam}

Kampung Batik Palbatu berupaya memberdayakan warga melalui kegiatan memproduksi batik dengan pewarna alam yang proses pembuatannya ramah lingkungan. Para warga dilatih menjadi pembatik-pembatik handal yang mampu memproduksi kain batik dengan kualitas terbaik. Kain-kain batik warna alam yang diproduksi akan melalui proses yang panjang, melibatkan banyak pekerja serta dengan tingkat ketelitian tinggi, sehingga menghasilkan kain batik warna alam dengan kualitas premium. Corak batik yang dikembangkan dan diproduksi adalah pengembangan dari corak betawi yang sudah ada sebelumnya.

\section{Belajar Membatik - Sanggar Batik}

Melalui sanggar-sanggar batik, kampung batik Palbatu berupaya memberikan pengajaran membatik kepada sebanyak mungkin orang, baik anak-anak maupun dewasa. Sasaran peserta sanggar ini adalah anak-anak di lingkungan kampung batik Palbatu dan sekitarnya, siswa-siswi SD, SMP, SMA dan SMK Negeri serta swasta di seluruh Jakarta dan sekitarnya, siswa-siswi sekolah internasional di seluruh Jakarta dan sekitarnya serta mahasiswa dan masyarakat umum di Jakarta dan sekitarnya. Program belajar batik menjadi salah satu daya tarik utama kampung Batik Palbatu sehingga warga Jakarta dapat belajar batik tanpa harus pergi jauh ke daerah. Selain itu pengajar batik dari daerah juga didatangkan untuk mengajar batik di Jakarta. Ada empat anggota ibu-ibu yang mengurus dan mengelola kegiatan belajar membatik, yaitu: Ibu H. Mansur, Ibu Eka, Ibu Yuyun, dan Ibu Andrino. Kegiatan edukasi membatik ini dibantu oleh 15 warga setempat yang turut menjadi perintis terwujudnya Kampung Batik Palbatu. Kadang kegiatan membatik ini juga dibantu oleh mahasiswa IKJ atau DKV dari beberapa universitas yang melakukan kegiatan pengabdian masyarakat.

\section{Penjualan Batik - Toko / Gerai Batik}

Kampung Batik Palbatu akan berupaya menghadirkan sebanyak mungkin gerai-gerai atau toko-toko batik yang menjual kain batik atau pakaian batik yang siap pakai. Menjual batik di rumah diharapkan menjadi peluang usaha utama atau usaha sampingan bagi warga sebagai salah satu cara meningkatkan penghasilan. Pada awal peresmian kampung Batik Palbatu jumlah toko batik sampai 20 toko yang buka setiap hari senin - minggu, dari jam 9 pagi hingga jam 9 malam.

\section{Kegiatan Kampung Batik Palbatu}

Ngebatik Sekampung tanggal 2-6 Oktober 2013 merupakan kegiatan kreativitas seni dan budaya, yang dilaksanakan berdekatan dengan Hari Batik Nasional, sebagai bagian dalam pelestarian dan pengembangan batik (Gambar 3). Program ini biasanya membuat acara Ngebatik di Jalanan, Ngebatik di Dinding dan Belajar Membatik. Dana untuk kegiatan ini didapat dari dana sukarela warga atau dari para donatur pemerhati dan pencinta batik. Untuk pengecatan program sponsorship menjadi pendukung kegiatan ini dapat terealisasi. 


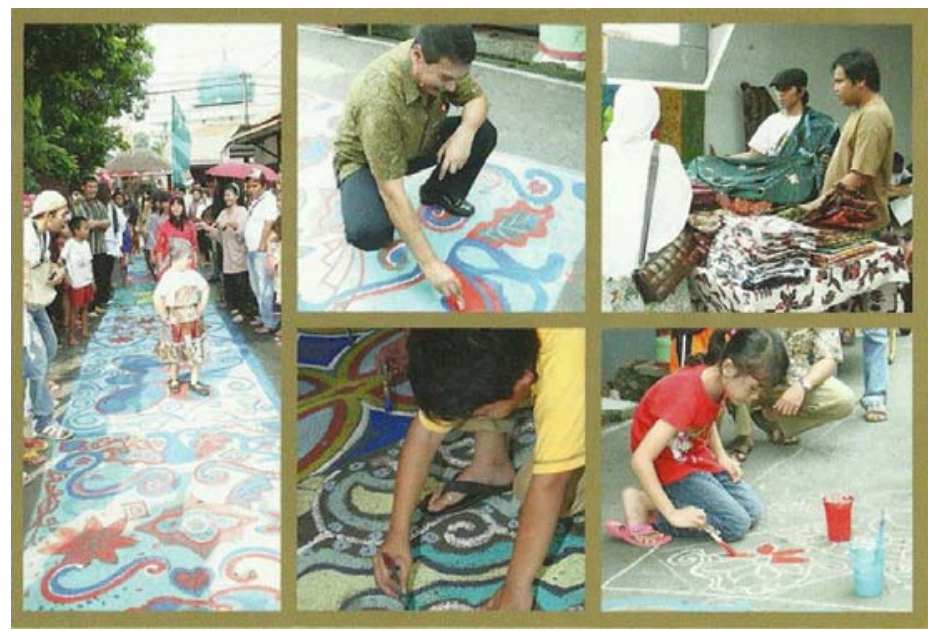

Gambar 3 Kegiatan Ngebatik Sekampung dalam rangka Hari Batik Nasional 2013 Sumber: Kampung Batik Palbatu, 2013

\section{Pola Tata Ruang Lingkungan Kampung Batik Palbatu}

Untuk mewujudkan kawasan permukiman di Palbatu, Menteng Dalam - Jakarta Selatan menjadi suatu kawasan wisata industri rumah tangga yang baru yaitu industri batik, sehingga dapat menjadi kawasan wisata budaya batik dan belanja batik, maka program urban renewal berupa penataan lingkungan perlu dilakukan. Urban renewal adalah upaya perawatan kembali suatu wilayah dengan mengganti sebagian atau keseluruhan unsur-unsur lama dengan unsur-unsur baru dengan tujuan untuk meningkatkan vitalitas dan kualitas lingkungan sehingga kawasan tersebut memberi kontribusi yang lebih baik bagi kota keseluruhan.

Peningkatan kualitas lingkungan yang akan dilakukan pada Kampung Batik Palbatu perlu dianalisis melalui identifikasi terhadap elemen-elemen pembentuk karakter lingkungan, antara lain batas yang jelas, karakteristik lingkungan dan pola tata ruang lingkungan yang ingin ditampilkan terlihat jelas, penanda kawasan yang jelas, ada area pusat kegiatan yang cukup mewadahi kegiatan dan sering didatangi pengunjung.

Keterangan Gambar:

Batas Kawasan Kampung Batik Palbatu

Utara : Jalan Palbatu 4

Selatan : Jalan Persada

Barat : Jalan Palbatu 7 dan

Jalan Palbatu 2

Timur : Jalan Palbatu 1

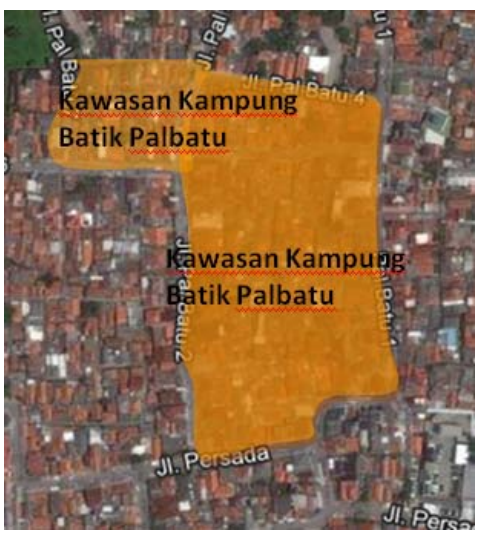

Gambar 4 Batas kawasan area kegiatan membatik di Kampung Batik Palbatu Sumber: Kampung Batik Palbatu, 2013. 
Batas kawasan Kampung Batik Palbatu secara fisik dibatasi oleh jalan lingkungan permukiman. Namun batas ini belum terlihat tegas menjadi dimanfaatkan sebagai penanda kawasan kampung batik. Hanya jalan Palbatu 4 dan lingkungan permukiman padat penduduk (area kampung batik Palbatu di sisi paling barat) yang terlihat memiliki karakter kampung batik melalui pengecatan jalan dan dinding rumah atau gang dengan pola dan corak batik.

\section{Karakteristik Lingkungan dan Pola Tata Ruang Kampung Batik Palbatu}

\section{Struktur Peruntukan lahan}

Merupakan salah satu komponen rancangan kawasan yang berperan penting dalam lokasi penggunaan dan penguasaan lahan/tata guna lahan yang telah ditetapkan dalam suatu kawasan perencanaan tertentu berdasarkan ketentuan dalam rencana tata ruang wilayah. Pada kawasan Kampung Batik Palbatu tata guna lahan cenderung merupakan permukiman (Gambar 5). Untuk mewujudkan kampung ini menjadi kampung batik, maka selain fungsi hunian di kawasan permukiman, ada penambahan fungsi untuk produksi batik dan penjualan batik pada rumah penduduk yang melakukan kegiatan membatik sebagai peluang usaha.

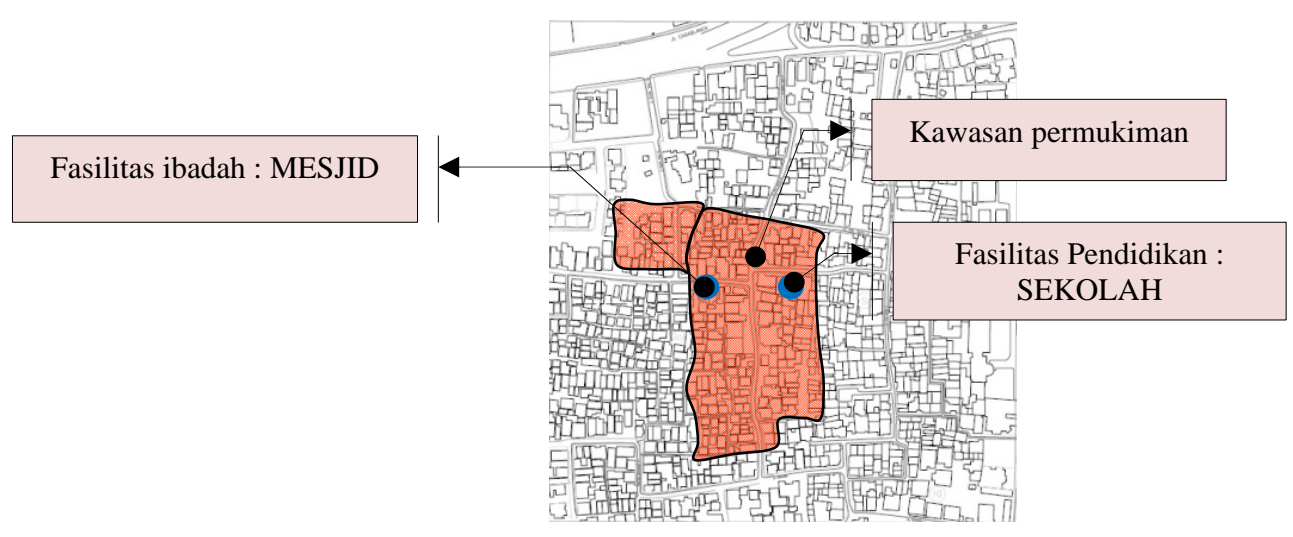

Gambar 5 Tata guna lahan di Kampung Batik Palbatu

Sumber: Hasil survei tim peneliti Binus, 2013

\section{Intensitas Pemanfaatan Lahan}

Merupakan tingkat alokasi dan distribusi luas lantai maksimum bangunan terhadap lahan/tapak peruntukannya untuk mencapai efisiensi dan efektivitas pemanfaatan yang adil. Komponen Penataan: (1) Koefisien Dasar Bangunan (KDB), yaitu angka persentase perbandingan antara luas seluruh lantai dasar bangunan gedung yang dapat dibangun dan luas lahan / tanah yang dikuasai. Secara umum, koefisien dasar bangunan di kawasan Palbatu berkisar antara 60 - 80 \%. (2) Koefisien Lantai Bangunan (KLB), yaitu angka persentase perbandingan antara jumlah seluruh luas lantai seluruh bangunan yang dapat dibangun dan luas lahan/ tanah yang dikuasai. Untuk koefisien lantai bangunan pada kawasan ini cenderung 1-2.

\section{Tata Bangunan}

Merupakan perencanaan pembagian lahan dalam kawasan menjadi blok dan jalan. Pada kawasan Palbatu khususnya kawasan Kampung Batik Palbatu, tata bangunan yang terbentuk terbagi menjadi dua tipe. Untuk tata bangunan yang berada di pinggiran jalan lingkungan tata bangunan teratur, sedangkan untuk tata bangunan pada pemukiman yang berada di dalam gang, tata bangunannya tidak teratur bahkan cenderung sporadis dan membentuk labirin (Gambar 6). 


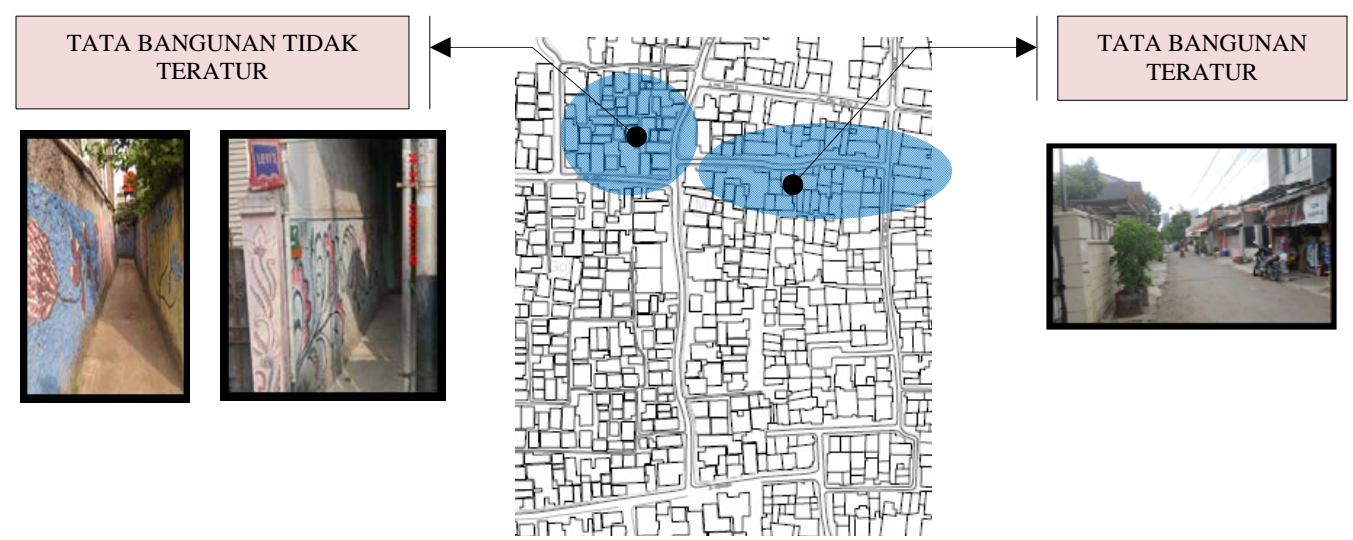

Gambar 6 Tata bangunan di Kampung Batik Palbatu Sumber: Hasil survey tim peneliti Binus, 2013.

\section{Sistem Sirkulasi dan Penghubung}

Terdiri dari jaringan jalan dan pergerakan, sirkulasi kendaraan umum, sirkulasi kendaraan pribadi, sirkulasi kendaraan informal setempat dan sepeda, sirkulasi pejalan kaki (termasuk masyarakat penyandang cacat dan lanjut usia), sistem dan sarana transit, sistem parkir, perencanaan jalur pelayanan lingkungan, dan system jaringan penghubung. Pada kawasan kampung batik, jaringan jalan merupakan jalan lingkungan di mana jalur sirkulasi kendaraan yang melalui jaringan jalan pada kawasan tersebut adalah kendaraan pribadi, ojek dan sepeda. Sedangkan untuk sirkulasi jalur pejalan kaki tidak ada termasuk sistem perparkiran yang cenderung menggunakan sistem parkir pada badan jalan (Gambar 7). Area parkir untuk menunjang kawasan wisata belum tersedia dan tidak terencana baik, sehingga untuk parkir pengunjung lebih sering menggunakan bahu jalan di jalan Casablanka untuk kendaraan besar seperti bis, dan di jalan lingkungan Palbatu untuk kendaraan kecil sampai mini bus.

Kondisi lingkungan yang belum siap menerima kunjungan orang dalam jumlah besar yang sering dikeluhkan warga setempat, karena lingkungannya menjadi ramai dan padat saat ada kunjungan, tetapi yang mendapat keuntungan hanya sebagian kecil warga yang aktif dalam kegiatan membatik.

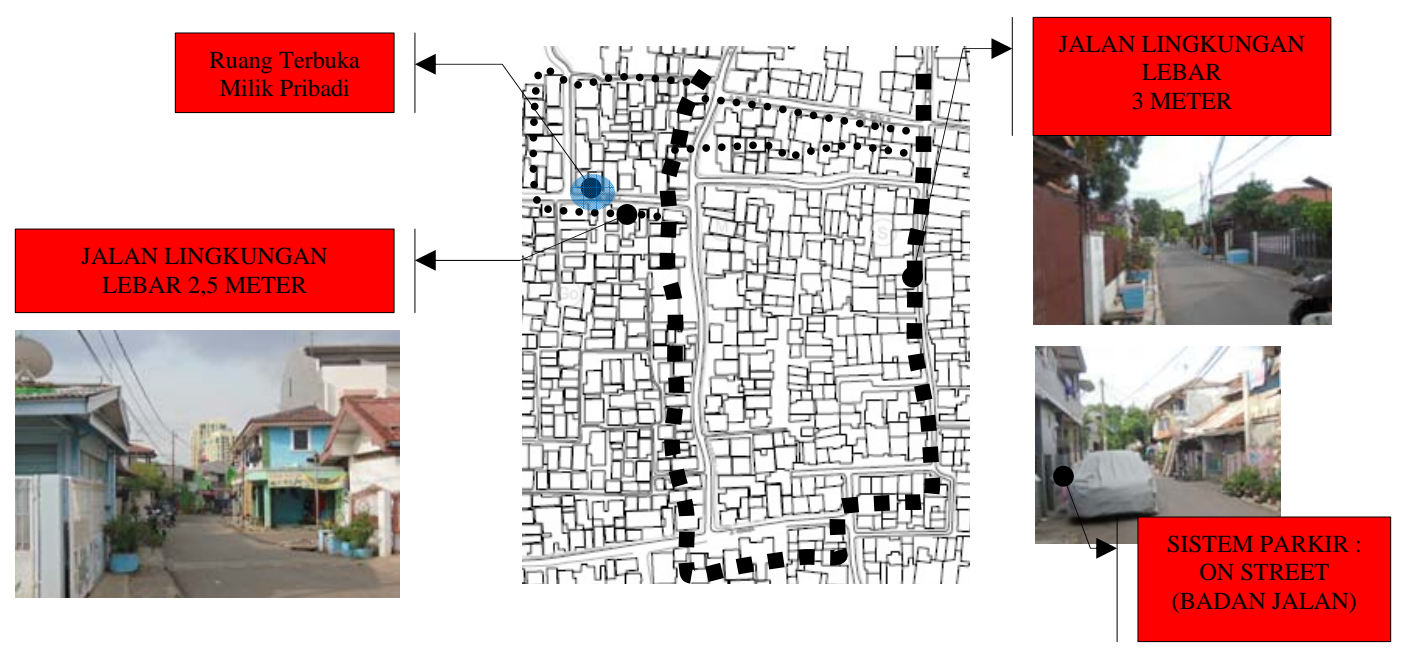

Gambar 7 Sistem sirkulasi dan penghubung,ruang terbuka serta parker yang menggunakan badan jalan di Kampung Batik Palbatu. Sumber: Hasil survey tim peneliti Binus, 2013. 


\section{Ruang Terbuka}

Merupakan komponen rancang kawasan, yang tidak sekadar terbentuk sebagai elemen tambahan ataupun elemen sisa setelah proses rancang arsitektural diselesaikan, melainkan juga diciptakan sebagai bagian integral dari suatu lingkungan yang lebih luas. Penataan sistem ruang terbuka diatur melalui pendekatan desain tata hijau yang membentuk karakter lingkungan serta memiliki peran penting baik secara ekologis, rekreatif dan estetis bagi lingkungan sekitarnya, dan memiliki karakter terbuka sehingga mudah diakses sebesar-besarnya oleh publik. Pada kawasan Kampung Batik Palbatu ruang terbuka hijau yang cukup luas sudah jarang ditemukan. Hanya ada satu ruang terbuka cukup luas milik pribadi di lingkungan permukiman padat penduduk (Gambar 7).

\section{Pusat Kegiatan Membatik di Lingkungan Kampung Batik Palbatu}

Kegiatan membatik oleh masyarakat yang ikut mengembangkan batik, dilakukan di rumahrumah mereka. Tujuannya adalah mereka masing-masing dapat mengembangkan peluang usahanya sendiri terkait batik. Dari sekitar 20 toko batik yang dibuka saat mulai didirikannya Kampung Batik Palbatu, saat ini jauh berkurang jumlahnya, beberapa diantaranya yang masih bertahan adalah toko batik Euis, toko batik Nona, dan tiga rumah batik (Gambar 8).

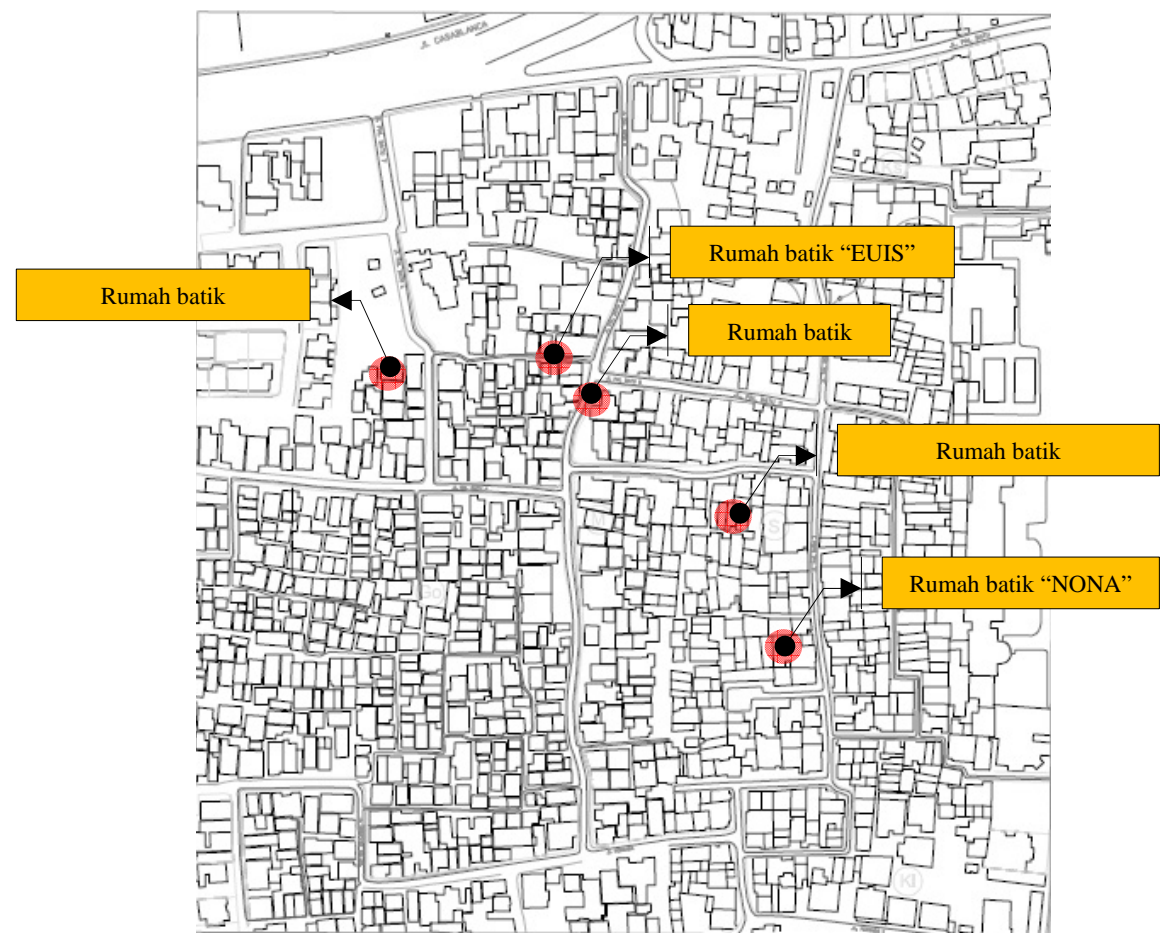

Gambar 8 Pusat kegiatan di Kampung Batik Palbatu Sumber: Hasil survey tim peneliti Binus, 2013.

\section{Potensi Kawasan Kampung Batik Palbatu}

Potensi kawasan Kampung Batik Palbatu dilihat dari sisi ekonomi, sosial dan budaya memiliki hasil penilaian yang berbeda, ada yang positif ada yang negatif. 
Tabel 1 Potensi Ekonomi Kampung Batik Palbatu

\begin{tabular}{lll}
\hline Potensi & Penilaian & Uraian \\
\hline Ekonomi & $(-)$ & Belum banyak warga Kampung Batik \\
& Masih kurang memberi dampak & Palbatu yang mengembangkan \\
& peningkatan ekonomi bagi warga & kegiatan batik sebagai peluang usaha. \\
& setempat. Lebih banyak potensi & Potensi ekonomi hanya bagi mereka \\
& dari sisi wisata edukasi dari pada & yang berminat dan membuka peluang \\
& wisata belanja batik. & usaha membatik. \\
\hline
\end{tabular}

Tabel 1 menunjukkan bahwa potensi ekonomi dari kegiatan membatik hanya dinikmati oleh warga setempat yang tertarik dan membuka usaha produksi dan penjualan batik. Namun menurut mereka hasilnya belum seperti yang mereka harapkan, karena kunjungan yang ramai hanya terjadi saat ada acara atau kegiatan membatik. Acara ini tidak rutin tiap hari, sehingga pendapatan dari usaha batik belum bisa diandalkan.

Kegiatan membatik memberikan dampak sosial yang sifatnya positif dan negatif (Tabel 2). Sisi positif terjadi karena ada interaksi positif yang saling menguntungkan antara masyarakat Kampung Batik Palbatu yang menyediakan kegiatan edukasi dan wisata belanja batik sehingga dapat manfaat ekonomi, dengan pengunjung yang ingin belajar membatik dan membeli batik di Jakarta sehingga tidak perlu ke luar kota.

Tabel 2 Potensi Sosial Kampung Batik Palbatu

\begin{tabular}{lll}
\hline Potensi & Penilaian & Uraian \\
\hline Sosial & $( \pm)$ & Masyarakat dilatih untuk menerima \\
& Kegiatan membatik & kunjungan dari pendatang yang \\
& menimbulkan adanya interaksi & melakukan wisata edukasi dan belanja. \\
& antara warga setempat yang & Namun ada juga warga yang terganggu \\
& menyediakan kegiatan dan & karena kegiatan membatik ini \\
& mencari keuntungan ekonomi, & menimbulkan keramaian akibat adanya \\
& dengan warga pendatang yang & kunjungan masyarakat dari luar \\
& ingin wisata edukasi atau belanja & Kampung Batik Palbatu. \\
& batik. & \\
\hline
\end{tabular}

Sisi negatifnya adalah masih banyak warga setempat yang kurang mendukung kegiatan membatik karena mereka tidak merasa mendapatkan manfaat ekonomi, bahkan lebih banyak merasa terganggu dengan adanya kegiatan membatik ini karena keramaian yang ditimbulkan akibat banyaknya kunjungan dari luar pada saat ada kegiatan membatik. Menurut mereka Kampung Batik Palbatu bukan untuk menerima kunjungan banyak orang karena kondisi lingkungannya tidak dirancang untuk kegiatan yang dapat menampung banyak kunjungan orang.

Kampung batik Palbatu juga tidak dirancang atau disiapkan sebagai kawasan industri rumah tangga, sehingga upaya mewujudkan Kampung Batik Palbatu sebagai kampung wisata edukasi budaya dan belanja batik belum berhasil dan berjalan lambat. Tidak banyak warga yang mendukung keberlanjutan kegiatan ini. Para perintis Kampung Batik Palbatu harus berjuang untuk mendapatkan bantuan dana atau subsidi dukungan bagi terselenggaranya acara-acara kegiatan edukasi membatik dan sosialisasi tradisi membatik. 
Upaya untuk mewujudkan Kampung Batik Palbatu sebagai kampung wisata edukasi budaya dan belanja batik masih butuh proses yang cukup memakan waktu lama. Dukungan dari warga setempat yang masih terbatas dan dukungan pemerintah yang belum maksimal (Tabel 3), membuat para penggagas dan tim perintis Kampung Batik Palbatu harus berjuang keras mewujudkan harapan mereka dalam rangka mencapai tujuan dikembangkannya Kampung Batik Palbatu sebagai salah satu wisata edukasi budaya dan belanja batik di Jakarta.

Tabel 3 Potensi Budaya Kampung Batik Palbatu

\begin{tabular}{lll}
\hline Potensi & Penilaian & Uraian \\
\hline Budaya & $(-$ ) & Kampung Batik Palbatu \\
& Jumlah toko batik berkurang sehingga hanya & tidak bisa berkembang \\
25\% dari awal pengembangan Kampung Batik & cepat menjadi kawasan \\
& Palbatu (hanya 5 toko/rumah batik masih & wisata budaya batik, \\
& aktif).Tidak banyak warga yang ikut & karena warga setempat \\
& berpartisipasi melestarikan budaya batik. & tidak memiliki keterikatan \\
& Belum banyak dukungan dari pemerintah & dengan tradisi membatik. \\
& setempat untuk membantu mengembangkan & \\
& kampung Batik Palbatu. & \\
\hline
\end{tabular}

Proses pengembangan Kampung Batik Palbatu yang berjalan lambat dapat dipahami, karena tidak mudah untuk memasukkan tradisi membatik pada masyarakat yang tidak memiliki latar belakang tradisi membatik. Kampung Palbatu dihuni oleh masyarakat dari berbagai budaya dan memiliki sumber penghidupan yang tidak terkait dengan kegiatan membatik. Sehingga upaya mewujudkan kampung batik di wilayah Palbatu yang muncul dari para penggagas dan perintis perlu proses dan waktu untuk mencapai keberhasilannya. Pelatihan dan acara-acara membatik yang memperlihatkan adanya keuntungan dari sisi ekonomi perlu sering diadakan sehingga masyarakat akan tertarik dan mulai ikut mengembangkan Kampung Batik Palbatu.

\section{SIMPULAN}

Hasil studi terhadap karakteristik tata ruang lingkungan kampung batik Palbatu menunjukkan bahwa kawasan ini kurang memiliki karakter kuat dan kurang jelas terlihat karakter lingkungan batik secara menyeluruh. Hanya sebagian area yang masih bertahan memiliki pusat kegiatan batik. Karakter batik yang dilukiskan di jalan, dinding dan pagar rumah juga sudah memudar. Untuk mempertahankan dan meningkatkan karakter kawasan sebagai kampung batik, perlu pengelolaan dan pemeliharaan berkala terhadap corak batik pada elemen jalan, dinding rumah bagian luar, dinding gang, dan pagar rumah.

Hasil studi terkait potensi yang ada di Kampung Batik Palbatu masih belum banyak. Hasil studi ini penting untuk dapat mewujudkan Kampung Batik Palbatu sebagai kawasan wisata industri rumah tangga, khususnya wisata edukasi budaya batik dan wisata belanja batik di Jakarta. Kampung Batik Palbatu belum memperlihatkan perannya dalam meningkatkan kesejahteraan masyarakat, dan masih kurang dukungan dari masyarakat setempat maupun pemerintah setempat. Untuk mewujudkan Kampung Batik sebagai kawasan industri rumah tangga khususnya batik, perlu dukungan masyarakat dan dukungan pemerintah setempat. Subsidi dana dari pemerintah dan swasta dapat membantu mempercepat perkembangan kampung wisata batik, antara lain untuk membantu pengembangan program dan acara-acara promosi wisata batik di kawasan Palbatu, atau untuk memperbaiki kualitas lingkungan agar karakter kawasan budaya batik dapat tampil atau jelas terlihat oleh masyarakat umum di Jakarta. 


\section{DAFTAR PUSTAKA}

Juvita, D. (2012). Sejarah Baru Kampung Batik di Jakarta, satulingkar.com/detail/read/9/805/sejarahbaru-kampung-batik-di-jakarta, April. Akses 11 Februari 2013.

Ramdlani, S. (2012). Urban Renewal; Peremajaan Kota dalam Perancangan Kota. Ramdlani.lecture.ub.ac.id/files/../urban-renewal.pp. Akses 11 Februari 2013.

Soeroto, M. (2003). Dari Arsitektur Tradisional Menuju Arsitektur Indonesia. Jakarta: Ghalia Indonesia. 